\title{
DEBATE
}

Debate is a series offering opposing sides of a continuing controversial issue in tobacco control. In this and the following article the issue of trade liberalisation around the world, and how it may affect the ability of governments to institute effective tobacco control policies, is debated by Douglas Bettcher from the World Health Organization in Geneva, Ira Shapiro from Washington DC, Cynthia Callard from Physicians for a Smoke-Free Canada in Ottawa, Hatai Chitanondh from the Thailand Health Promotion Institute in Bangkok, and Robert Weissman from Essential Action in Washington DC.

\section{Tobacco control in an era of trade liberalisation}

Although tobacco control forces around the world are agreed that tobacco companies will stop at nothing to keep selling cigarettes and find new smokers wherever they can, they are split on some important questions of how to proceed. One issue that has proven divisive has been whether the wave of trade liberalisation around the world leads to increased smoking and undermines the ability of governments to adopt tobacco control measures.

Those who hold those views make three points. First, they contend that trade liberalisation and market opening around the world has led, and will inevitably lead, to more smoking as the multinational cigarette companies increase their activities in developing countries. Second, they argue that the rules-based international trading system, of which the World Trade Organization (WTO) is the cornerstone, places unacceptable limits on countries' freedom to regulate tobacco and tobacco products. Third, based on the first two points, they conclude that tobacco and tobacco products should be treated as an exception to the international trade rules, so that trade in these products could be more readily restricted.

The best evidence to date does show a clear correlation between increased cross border trade and increased smoking. Chaloupka and Laixuthai ${ }^{1}$ concluded that there was a substantial rise in the market share of US cigarettes in countries in which the USA aggressively pursued market opening measures. Overall smoking in the affected countries was $10 \%$ higher than it would have been if markets had remained closed to US cigarettes. This result comes about because the reduction of trade barriers reduces the price of imported cigarettes, and, in the absence of government regulation, increases the expenditure on cigarette advertising. Moreover, if the combination of lower prices, greater availability, and increased advertising of foreign cigarettes were not enough, young people and women are often the targets of the most intensive advertising, so the incidence of smoking increases most sharply in those categories. A related study suggests that while reduced trade barriers have no significant impact on smoking in high income countries, it has a small but significant impact on consumption in middle income countries, and a significant impact on low income countries. ${ }^{2}$
But if the evidence is clear that increased trade results in increased smoking, that correlation alone does not point the way to the right policy response. Chaloupka and Laixuthai express the fear that discriminatory tobacco control policies and high trade barriers will invite sanctions and/or retaliatory measures under the trade agreements, affecting trade in other goods and services. ${ }^{1}$ Their report observes that strong tobacco control policies aimed at reducing the health consequences of tobacco use are consistent with international trade agreements; these are the policies that should be followed. Similar recommendations are made by the World Bank in its report, "Curbing the epidemic". ${ }^{3}$

Our concern is that some of the strongest voices in the global effort to reduce tobacco use have directed much of their assault on the international trading system, the WTO, and globalisation generally. Certainly, demonising the WTO and attacking globalisation guarantees a sizeable audience. But we believe that these views reflect a fundamental misunderstanding of the trading system, and unnecessarily drives a wedge between tobacco control advocates who should be united.

We start from the belief that it is not acceptable for international trade to produce economic growth, as important as growth is, if that growth comes at the expense of other cherished values, such as environmental protection, worker and consumer safety, or public health. We would not support the rulesbased international trading system, and the effort to liberalise trade, if we thought it infringed on the ability of nations to regulate tobacco and cigarettes in order to reduce tobacco use.

\section{GATT rules}

But the international trade rules do not deprive countries of their ability to take tobacco control measures. Concerned nations can take a broad and imaginative range of actions to reduce tobacco use within the rules of the trading system. Article $\mathrm{XX}(\mathrm{b})$ of the General Agreement on Tariffs and Trade (GATT), now incorporated into the WTO, contains a clear exception to the general proposition of open trade. It establishes that nothing in the GATT or WTO agreements prevents countries from enacting measures "necessary to protect human, animal or plant life or health," as long 
as those measures "are not applied in a manner which could constitute an arbitrary or unjustifiable discrimination between countries, or a disguised restriction on trade."

In 1990, at the request of the USA, a GATT panel considered an array of measures that Thailand had enacted to reduce smoking, including an import ban and an advertising ban. The panel clearly accepted, as its starting point, Thailand's authority under article $\mathrm{XX}$ (b) to enact measures to reduce the consumption of cigarettes because cigarettes posed a serious risk to public health. The panel concluded that Thailand's import ban was contrary to Thailand's international obligations because it plainly discriminated against foreign products, but went on to establish broad latitude for Thailand (and other countries) to enact measures to regulate smoking on a non-discriminatory basis. The measures that could be implemented included ad valorem taxes, advertising bans, price restrictions, ingredient disclosures, strong warning labels, and even a ban on brand name or imagery.

Following the decision, Thailand was able to implement its existing advertising ban, which made it, according to the multinational tobacco control companies, more difficult for foreign cigarette companies to compete with the established domestic monopoly. It enacted a law to require the complete disclosure of all of the ingredients of all tobacco products. Thailand was also able to implement measures allowing the Ministry of Health to determine all aspects of labelling, including health warnings; to ban vending machine sales, distribution of free samples, exchanges and gifts of cigarettes; to ban tobacco advertising (including the use of cigarette logos and other symbols on tobacco products), except in international magazines and on live broadcasts originating outside of Thailand; to ban advertising products with the same name as tobacco products; to ban producing, importing, advertising and selling products imitating tobacco products; and to ban the sales of cigarettes not complying with Thailand's labelling provisions. Following the implementation of these tobacco control measures over the past 10 years, Thailand's smoking prevalence rate among males over 11 years has decreased from $48.9 \%$ in 1991 to $38.9 \%$ in 1999, while smoking prevalence rates among females over 11 years has remained very low at $2.4 \%$ in 1999 , a figure that reflects a decrease from $3.8 \%$ in 1991.4

Since the creation of the WTO in 1995, and possibly in light of intensified public interest, the jurisprudence respecting the authority of countries to enact measures protective of public health has become even stronger. Recently, a WTO adjudicating panel* upheld a French ban on asbestos that was challenged by Canada. ${ }^{5}$ The panel recognised that although the French ban was incompatible with the national treatment provisions of article III,

*Canada appealed this decision to the WTO Appellate Body; a final decision is expected in March 2001.
France nevertheless had a right to apply the ban under GATT article XX(b) in order to "protect human, animal or plant life or health." In our view, article $\mathrm{XX}(\mathrm{b})$, interpreted in the Thai cigarettes case ${ }^{6}$ and this recent asbestos case, means that there is nothing in the trading rules that stop a member country from regulating cigarettes and other tobacco products stringently.

Policy decisions on tobacco control have been challenging because many nations, including the USA, have long been tobacco growers and cigarette manufacturers. Many governments around the world derive substantial revenues from tobacco taxes. Moreover, tobacco is not an illegal crop, cigarettes are not an outlawed product, and smoking is not an illegal practice. It is these factors that stop governments from moving as rapidly and comprehensively as they should against the scourge of tobacco use, rather than the rules of the WTO, or the imperatives of globalisation.

\section{US trade policy}

The track record of the USA over the past decade makes it clear that policy choices, not WTO rules, determine whether a country combats smoking or promotes it. In the 1980 s, during the Reagan and Bush administrations, it was the trade policy of the USA to work aggressively to open foreign markets for US cigarette exports. The Office of the US Trade Representative launched investigations of various Asian countries and the trade barriers they maintained to insulate their domestic monopolies from competition of US cigarette companies. The aggressive market opening efforts attacked discriminatory practices and non-discriminatory public health practices as well, as the panel decision in Thai cigarettes case showed. ${ }^{6}$ As the cited studies report, these US efforts increased the sale of US cigarettes in the targeted countries, and the incidence of smoking, particularly among young people and women.

When the Clinton administration took office in 1993, US Trade Representative Mickey Kantor focused on the question of whether the US government should be using its resources to pressure the country's trading partners to open markets to US cigarette exports. Kantor concluded that the US government should not be doing so, and promulgated policy accordingly. He also worked with Health and Human Services Secretary Donna Shalala on an interagency task force to promulgate policy for the whole administration.

The Clinton administration policy received its most explicit and unequivocal statement in an unclassified cable sent to all US embassies by Secretary of State Madeline Albright in February $1998 .^{7}$ That cable noted that "while opening foreign markets for US exporters and removing barriers to international trade were high priorities for the United States government, the United States respects the rights of foreign governments to establish and maintain sound public health practices, encourages them to do so, and where appropriate, may support such efforts with 
multilateral and bilateral assistance." The cable goes on to note "that tobacco use will be the leading global cause of premature death and preventable illness in the 21 st century," and therefore "the US government will not promote the sale or export of tobacco or tobacco products or seek the reduction or removal by any foreign country of non-discriminatory restrictions on the marketing of tobacco or tobacco products." Deferring in part to domestic political realities, the cable candidly notes that "the overall objective of this policy is to ensure equal access to a shrinking global market for tobacco." But the cable instructs ambassadors and embassy staff to avoid attending or involving themselves in any event that could be construed as US government support for the sale or export of tobacco or tobacco products. Interestingly, even in the case where an embassy comes across a regulation that is discriminatory, the cable requires the embassy to inform Washington, for consultation with the trade and health agencies, rather than protest it.

The administration's policy was put in law by Congress in the Doggett amendment to the 1998 State, Justice, Commerce Appropriations Act. That amendment states that "none of the funds provided for by this Act shall be available to promote the sale or export of tobacco or tobacco products, or to seek the reduction or removal by any foreign country of restrictions on the marketing of tobacco or tobacco products, except for restrictions which are not applied equally to all tobacco or tobacco products of the same type."

During the past eight years, the Clinton administration worked hard to combat the cigarette companies on all fronts in the USA, including, for the first time, the Food and Drug Administration (FDA) seeking to regulate nicotine as an addictive drug. Inevitably, the cigarette companies were going to respond to the costs of any tobacco settlement in the US by seeking to increase sales around the world. The administration's trade policy reflected the view that it would be hypocritical to work to reduce smoking in the USA, while supporting the efforts of US cigarette companies to recruit replacement smokers around the world. These were policy choices; neither the forces of globalisation nor the rules of the trading system required these decisions, nor prevented them from being taken. There is nothing to stop the USA, for example, from requiring its cigarette companies to observe the same limits on advertising and to ensure they comply with the labelling requirements of every country in which they sell cigarettes.

We are committed to reducing tobacco use worldwide as much as possible, to reduce the death and disease that will inevitably accompany it. If we thought that carving tobacco and tobacco products out of the international trading system in order to prohibit trade in cigarettes and other tobacco products could be accomplished, we would certainly support it. But what the advocates of this position fail to recognise is that if the political will existed globally to take tobacco and tobacco products out of the trading system, we would be facing a radically different-and much easier-problem than we actually confront. The importance of tobacco control makes it imperative to deal with the world as it exists, rather than as we might like it to be. In the worldwide battle to control tobacco and reduce smoking, making realistic battle plans and choosing the right battlefields are crucial.

Trying to take a global public health issue, and debate it in the international trade realm, is a formula for frustration and failure. It is impossible to envision how stressing the trade aspects of the issue, and seeking some negotiated change in the trade rules under auspices of the WTO, can advance the objectives of tobacco control. The WTO is already staggering under the weight of the current trade agenda. Against this background, it is far preferable to continue working globally through the WHO and the negotiation of the Framework Convention on Tobacco Control where public health issues predominate, consensus can be built, and real progress can be attained. Ironically, opting for the WTO would advance the interests of the tobacco companies, who would like nothing better than to see tobacco control advocates bogged down in a trade debate that is already inflamed enough.

We are still far from enacting maximum, non-discriminatory tobacco control policies at the local, national, and global levels. What is needed is a coherent, global approach of advocating best practices to strengthen tobacco control policies as a preventive strategy before or alongside trade liberalisation.

Coordinator,

DOUGLAS BETTCHER

Framework Convention on Tobacco Control,

Tobacco-Free Initiative,

World Health Organization,

Geneva, Switzerland

Long, Aldridge E Norman,

IRA SHAPIRO Washington DC, USA

Ira Shapiro served in the office of the US Trade

Representative from 1993 to 1997, as General Counsel and Trade Ambassador.

1 Chaloupka FJ, Laixuthai A. US trade policy and cigarette smoking. In: Asia National Bureau of Economic Research. Working Paper No 5543, 1996.

2 Taylor A, et al. The impact of trade liberalization on tobacco consumption. In: Jha P, Chaloupka FC, eds. Tobacco control policies in developing countries. Oxford: Oxford University Press, 2000:343-64

3 The World Bank. Curbing the epidemic: governments and the economics of tobacco control. Series: Development in practice. Washington DC, 2000. http://www.who.int/toh/ worldbank/wbr.html

4 Report of the Health and Welfare Survey', National Statistics Office of Thailand, Office of the Prime Minister. Various years. http://www.ash.or.th/situation/prevalence.htm

5 World Trade Organization., European Communitiesmeasures affecting asbestos and products containing asbestos, Panel Report DS135/R, Geneva, World Trade Organization, 18 September 2000

6 GATT Panel. Thailand-restrictions on importation of and internal taxes on cigarettes. Report BISO $375 / 200$. Geneva:
General Agreement on Tariffs and Trade Secretariat, 7 November 1990.

7 Department of State Cable 027439, 14 February 1998, (unclassified), concerning "Tobacco: Guidance for US Diplomatic Posts on Health, Trade and Commercial Issues". 